\title{
Dijitalleşen Biyolojik Yurttaşlık: Change.Org Örneği
}

\author{
Mehmet Emin SATIR*
}

Öz

Yeni bir yurttaşlık tipi olarak biyolojik yurttaşlık olgusu, hastalıklar, bedensel kusurlar ve eksiklikler ekseninde bir araya gelen bireylerin oluşturduğu yurttaşlık biçimini nitelendirmektedir. Biyolojik kökenli nedenlerden ötürü bir araya gelerek iktidarlardan, birtakım sosyal haklar talep eden biyolojik yurttaşlar, küreselleşme sonrası çağda oldukça etkili faaliyetler yürütmektedirler. Bu bağlamda biyolojik yurttaşlık olgusunda direkt olarak birey ve iktidar arasında bir ilişki söz konusudur. Yeni medya teknolojilerinin de gelişim göstermesiyle biyolojik yurttaşlık faaliyetleri, internet ortamlarında yürütülmeye bașlamıștır. Bu bağlamda yapılmış olan bu çalıșmanın amacı, biyolojik yurttaşlık olgusunu yeni medya teknolojileri ekseninde tartışmaktadır. Çalışmada, literatür tarama yöntemi kullanılmış olup, online bir aktivizm platformu olan Change.org'un 2015-2018 yılları arasındaki raporlarda yer alan sağlı konulu kampanyalar ve bu kampanyalara yönelik katılımlar, biyolojik yurttaşlık ekseninde tartışılmıştır. Dijitalleşme

Anahtar Kelimeler: Biyolojik Yurttaşlık, Yeni Medya, Sağlık, Change.org,

\section{Digitalized Bio-Citizenship: Case of Change.Org}

\section{Abstract}

As a new type of citizenship, the phenomenon of biological citizenship characterizes the form of citizenship formed by individuals coming together in the axis of diseases, physical defects and deficiencies. Biological citizens, who come together for reasons of biological origin and who demand some social rights from the government, carry out highly effective activities in the post-globalization period. In this context, there is a direct relationship between individual and power in the case of biological citizenship. With the development of new media technologies, biological citizenship activities have started to be carried out in internet environments. In this context, the aim of this study is to discuss the phenomenon of biological citizenship on the axis of new media technologies. In this study, literature review method was used. Also in this study, The campaigns on health and participation in these campaigns were discussed on the axis of biological citizenship in the 2015-2018 report of Change.org, an online platform for activism.

Özgün Araştırma Makalesi (Original Research Article)

Geliş/Received: 11.04.2019

Kabul/Accepted: 10.02 .2020

DOI: https://dx.doi.org/10.17336/igusbd.552119

* Arş. Gör., Necmettin Erbakan Üniversitesi, Sosyal ve Beșeri Bilimler Fakültesi, Halkla İlișkiler ve Reklamcılık Bölümü, Konya, Türkiye, E-posta: mehmeteminsatir@gmail.com 
Keywords: Biocitizenship, New Media, Health, Change.org, Digitalization

\section{Giriş}

Küreselleşme ve neo-liberal politikaların hız kazanmasıyla birlikte farklı yurttaşlık tiplerinin tartışıldığı görülmektedir. Özellikle de hastalıklar ve biyolojik kusurlar ekseninde birleșen bireylerin bir araya gelerek oluşturmuş oldukları biyolojik yurttaşlık kavramı, bu çerçevede önem arz etmektedir. İlk olarak 2002 yılında Adriana Petryna tarafından Çernobil Faciası'na ilişki yapmış olduğu çalışmada kullanılan biyolojik yurttaşlık kavramı, benzer biyolojik sorunlara sahip bireylerin bir araya gelmeleriyle oluşturdukları toplulukları nitelendirmek için kullanılmaktadır. Petryna, biyolojik yurttaşlık kavramını Çernobil vakası özelinde yapmış olduğu çalışmada radyasyona maruz kalan bireylerin, devletten birtakım sosyal haklarda bulunmalarına ilișkin yapmıș olduğu çözümlemeler ışığında ortaya koymuştur. Sonraki dönemlerde de birçok araștırmacı tarafından çalıșllan biyolojik yurttaşlık olgusu, sosyal adalet, sağlık hakları ve beden politikalarına ilișkin önemli bir tartışma alanı yaratmaktadır.

Biyolojik kusurlar ekseninde bir araya gelen yurttaşların oluşturmuş olduğu biyolojik yurttaşlık kavramının izlerini yeni medyanın yükselișe geçtiği dönemde de gözlemlemek mümkündür. Bu bağlamda yapılmış olan bu çalışmada yeni medya ve internet teknolojileri bağlamında biyolojik yurttaşlık olgusunun dijitalleşmesi durumu üzerinde durulmuştur. Yeni medya ve internet teknolojileri, bireylerin bir araya gelerek, kolektif sanal cemaatler oluşturmalarının önünü açmış ve bu durum biyolojik yurttaşlık olgusunda da kendisini göstermektedir. Dolayısıyla bu çalışmada biyolojik yurttaşlık olgusu, yeni medya ve internet teknolojileri ekseninde change.org özelinde tartışılmıştır.

Çalışmada ilk olarak biyolojik yurttaşlık olgusu üzerinde durulmuş ve Adriana Petryna, Nicolas Rose ve Carlos Novas gibi düşünürlerin fikirlerinden hareket edilerek, biyolojik yurttaşlık olgusu anlamlandırılmaya çalışılmıştır. Sonraki aşamada ise yeni medya ve internet teknolojilerinin gelşim göstermesi ile biyolojik yurttaşlığın dijitalleşmesi arasındaki ilişki irdelenerek, biyolojik yurttaşlık ve dijitallaşme üzerine tartışılmıştır. Son olarak ise bir sanal aktivizm platformu olan change.org özelinde biyolojik yurttaşlık ve dijital biyolojik yurttaşlık tartışması yapılmıştır. Çalışmada literatür taraması yöntemi kullanılmış olup çalışma, Change.org platformunun yayımlamış olduğu 2015-2018 yılı faaliyet raporu ile sınırlandırılmıştır. 2018 yılında sağlık alanında başlatılan kampanyaların 9'u başarıya ulaşmıştır. 2017 yılında ise sağlık alanında bașarıya ulaşan kampanya sayısı 6'dır. Bu sayı 2016 yılında on bir, 2015 yılında ise on beștir. Bu bağlamda çalıșmada yargısal/amaçsal örnekleme tekniğiyle seçilen, başarıya ulaşmış 5 kampanya üzerinde durulmuştur. Seçilen örneklemler üzerinden hareketle çalışmanın temel savı, yeni medya ve internet teknolojilerinin -Change.org özelinde- biyolojik yurttaşlık ekseninde kullanılabileceğini ortaya koymaktır.

\section{Dijital Aktivizm}

Yeni medya teknolojilerinin gelişim göstermesiyle birlikte birçok toplumsal dönüșüm yașanmıștır. Bu dönüşümlerden birisi de olan toplumsal hareketlilikler ve eylemlerdir. İnternet teknolojilerinin gelișim göstermesi, bireylerin kamusal sorunlara aktif katılım sağlayabilmesini kolaylaştırmıştır. Bireyler, internet teknolojileri sayesinde sorunlarını, hoșnutsuzluklarını ve düşüncelerini, sanal mecralarda rahatlıkla dile getirebilmektedir. Aktivizm, genel olarak sosyal değişim için harekete geçme durumu olarak tanımlanmaktadır. Sosyal değişime yönelik eylemler; kitle hareketleri, lobi faaliyetleri, sivil itaatsizlik eylemleri ve mitingler şeklinde yürütülmektedir. İnternet 
teknolojilerinin gelişim göstermesiyle birlikte aktivizm, dijital bir hale dönüşmeye başlamıştır ve günümüzde değişim odaklı eylemler, internet üzerinden yapılmaktadır (Chibata, 2016, s.70).

İnternet teknolojilerinde meydana gelen köklü değișiklikler, değișime yönelik sosyal mahiyetteki eylemlerin de zemininde değișikliğe yol açmıştır. Günümüzde birçok sosyal sorun, internet üzerinden tartışılmaktadır. $\mathrm{Bu}$ durum da aktivizmin dijitalleşmesine neden olmaktadır. Özellikle sosyal medyanın kullanımının yaygınlaşmaya birlikte, dijital aktivizm kavramı sıklıkla gündeme gelmeye başlamıştır. İnternet, akıllı telefonlar ve diğer web tabanlı araçlarla gerçekleştirilen siber aktivizm ya da dijital aktivizm de klasik aktivizm türlerinde olduğu gibi organize olmak, harekete geçmek ve farkındalık yaratmak amacıyla gerçekleștirilmektedir (Radsch, 2016, s.31). Dijital aktivizmde bir sorun etrafında birleșen bireyler, kamusal uzamda değil., siber bir uzamda eylemde bulunmaktadırlar. $\mathrm{Bu}$ da dijital aktivizmin, bilinen aktivizm faaliyetlerinden farklılaştığı noktayı işaret etmektedir. Özellikle sosyal medya aracılığıyla örgütlenen bireyler, belirli konularda harekete geçmek üzere "sanal eylemlerde" bulunmaktadırlar. Ayrıca change.org, avaaz.org ve care2.com gibi sitelerde de aktivizm faaliyetleri yürütülmektedir. Bireyler, internet teknolojileri sayesinde belirli konular ekseninde toparlanıp, "sanal cemaatler" oluşturmaktadırlar. Ortak bir amaç doğrultusunda harekete geçen bireyler, internet tabanlı teknolojiler sayesinde siber ortamda eyleme geçmektedirler. Bu çerçevede biyolojik yurttaşlık olgusu da dijital aktivzm bağlamında değerlendirilmektedir. Özellikle belirli sağlık sorunlarına sahip olan bireyler, internet tabanlı teknolojiler sayesinde sanal ortamda örgütlenebilmekte ve seslerini yetkili kurum ve kuruluşlara duyurabilmektedirler. Bu noktadan hareketle eylemin siber hali olarak nitelendirilebilecek olan dijital aktivizm, günümüzde kitlelerin siyasal katılım, kendilerini ifade etme ve politik tutumlarının oluşumu noktasında işlevsel bir özelliğe sahiptir (Dennis 2019, s.16).

\section{Biyolojik Yurttaşlık Olgusu}

Biyolojik yurttaşlık/bioyurttaşlık olgusu, ilk olarak 2002 yllında Andriana Petryna tarafından Çernobil faciası üzerinde yapmış olduğu çalışmada kullanılmıştır. Petryna, çalışmasında biyolojik yurttaşlığı, biyolojik olarak zarar görmüş bir nüfusun bireysel ya da kolektif olarak refah iddiasında bulunması durumu olarak tanımlamıștır (Cooter, 2008). Yeni bir kavram olan biyolojik yurttaşlık, özellikle iktidarın kabuk değiştirip, biyolojik bir iktidar haline gelmesiyle belirginlik kazanmaya başlamıștır. Petryna'nın Ukrayna'daki Çernobil Nükleer Santrali'nde meydana gelen felaket üzerinden tanımlamaya çalıştığı biyolojik yurttaşlık, herhangi bir biyolojik sorun etrafında birleșerek, toplumsal ve politik bir güç unsuru oluşturan kişileri tanımlamak için kullanılmaktadır. AIDS, kanser, otizm ve diğer kronik hastalıklara maruz kalanlar ve yakınlarının oluşturmuş olduğu bu topluluklar, mevcut sağlık sorunlarına ilişkin olarak köktenci bir yaklaşımı benimsemektedirler (Terzioğlu, 2011, s. 130).

Biyolojik yurttaşlık olgusunun ilk olarak gözlemlendiği yer olan Ukrayna'da Çernobil felaketi sonrasında Ukrayna nüfusunun yaklaşık olarak \%7'sinin oluşturmuş olduğu grup, mevcut yönetimden sosyal destek ve birtakım sosyal haklar talep etmek için acı çeken statülerini kullanmışlardır. Petryna için bu grup ve grubun öne sürmüș olduğu iddialar, ortak bir ulusal bölge, kültür veya inanç sistemi yerine biyolojik olarak radyasyona maruz kalma derecesi üzerinden temellendiği için, yeni bir tür vatandaşlık teşkil etmekteydi (Greenhough, 2014, s. 1; Petryna, 2002). Bu bağlamda biyolojik yurttaşlığın dayanak noktasının kültür, din, dil ya da diğer değerler yerine sahip olunan biyolojik rahatsızlıklar olduğu ileri sürülebilir. $\mathrm{Bu}$ bağlamda Petryna'nın kavramsallaştırmış olduğu biyolojik vatandaşlık tipi, yeni bir vatandaşlık tipini 
imlemektedir. Petryna'nın yapmış olduğu çalışmadan sonra biyolojik yurttaşlık olgusu üzerinde çalışmalar yapılmaya devam etmiștir. Nicolas Rose ve Carlos Novas, biyolojik yurttaşlığın siyasi tartışmalar için yeri mecralar açtığını ve demokrasi için yeni sorular ortaya çıkarttığını vurgulayarak, yeni aktivizm biçimlerini de yarattığını ileri sürmüşlerdir. Ayrıca Rose ve Novas, biyolojik vatandaşlığı, haklar, sorumluluklar ve görevler gibi etik bir perspektif üzerinden tartışmaktadırlar. (2005, s. 442; Plows ve Boddington, 2006, s. 119).

Beden ve bedenin sahip olduğu hastalıklar, eksiklikler ve kusurlar üzerinden temellenen biyolojik yurttaşlık tartışmaları, yurttaşlık olgusunun da tartışmaya açılmasına neden olmaktadır. Biyolojik yurttaşlık tartışmaları, Antik Yunan siyasetindeki "yurttaşlık" kavramını diriltmektedir. Yurttaşlık, Yunan polis devletlerinde, bireyin özel hayatının bir kamu meselesi olduğu ve bireyin yükümlülüklerinin toplumun günlük işleyișine bağlı olduğu bir döneme gönderme yapmaktadır. 0 dönemlerde yurttaşlık salt bir siyasi topluluğa üye olmanın neticesinde elde edilen bireysel haklar olarak görülmemektedir. Aksine, yurttaşlık, yurttaşlık bilgisinin ahlaki erdemlerini aktif olarak gösterip, yurttaşın toplumun yaşamını ve refahını geliştirmeye yönelik bilinçli bir devletyurttaş ilişki ekseninde tanımlanmaktadır. Bu bağlamda biyolojik yurttaşlık tartışmalarının temelinin Antik Yunan Polis devletlerindeki "yurttaşlık" tanımlamasıyla örtüştüğü ileri sürülebilir (Halse, 2009, s. 50).

Yurttaşlık tartışmalarını şekillendiren ve yeni bir yurttaşlık formu olarak ortaya çıkan biyolojik yurttaşlık olgusu Rose'a göre üç temel soru üzerinden mevcudiyetlerini şekillendirmektedirler. "Ne Bilebilirim?", "Ne Yapmalıyım" ve "ne umabilirim" soruları üzerinden biyolojik yurttaşlık vazifelerini yerine getiren biyolojik yurttaşlar, beklenti ve talepleriyle toplumsal ve siyasal yaşamda etkili olmaktadırlar (Rose, 2008, s. 47). Dolayısıyla biyolojik yurttaşlık, temelde beden üzerinden temellenen istekler noktasında varlık göstermektedir. Bedensel hastalıklar ve eksikliklerin bir araya getirdiği kişiler, oluşturmuş oldukları kolektif yapılar aracılığıla iktidarlardan taleplerde bulunmaktadırlar. Bu noktada ana unsurun biyolojik eksiklik ve hastalıklar olduğunun belirtilmesi gerekmektedir. Biyolojik yurttaşlık olgusunun alametifarikası, bedensel hastalıklar ve bedenin kusurlarıdır. Bu bağlamda biyolojik yurttaşların bir araya gelerek oluşturmuş oldukları yapıların temelinde tıpkı Çernobil faciasında olduğu gibi, biyoloji kaynaklı unsurlar yer almaktadır.

\section{Yeni Medya Teknolojilerinin Gelişimi ve Dijitalleşen Biyolojik Yurttaşlık}

Yeni medya teknolojilerinin gelişim göstermesi, modern bireyin toplumsal yaşamında birtakım değişim ve dönüşümler yaratmıştır. Temelde internet ortamı, cep telefonları ve oyun konsolları gibi web tabanlı dijital teknolojiler üzerinden tanımlanan yeni medya olgusu, geleneksel medyadan birçok noktada farklılaşmaktadır. Bu bağlamda yeni medya teknolojilerinin, geleneksel medyadan farklılaștığı en önemli iki noktanın etkileşimsellik ve multimedya özellik göstermesi olduğu söylenebilir (Binark, 2007, s. 21). $\mathrm{Bu}$ bağlamda geleneksel medyadan farklı olarak yeni medya teknolojileri, iletişim olgusunda bir kırılma yaratmıştır. Geleneksel medyanın tek yönlü, jakoben özelliklerine karşıt olarak yeni medya teknolojileri, kullanıcılarına içeriğin tüketicisi statüsünden, aynı zamanda içeriğin üreticisi olabilme hakkını tanımaktadır. Bu bağlamda yeni medya teknolojilerinin gelişi ile birlikte iletişim olgusunun birtakım değişim ve dönüşümler yaşadığını belirtmek gerekmektedir.

Temelde internet tabanlı olarak geliştirilen yeni medya teknolojileri, iletişimin küresel düzlemde gelişmesine ve enformasyon toplumunun ortaya çıkmasına yol açmıştır. Manuel Castells'in ağ toplumu olarak nitelendirdiği günümüz toplumsal dinamiklerinin arka planında kuşkusuz internet temelli teknolojiler bulunmaktadır 
(Castells, 2008). Yeni medya ve toplumsal sonuçlarına dair iyimser ve kötümser görüşler varlık gösterse de, yeni medya ve internet teknolojilerinin toplumsal düzlemdeki etkilerinin görmezden gelinmemesi gerekmektedir. We Are Social platformunun 2019 verilene göre, 7 milyar 676 milyonluk Dünya nüfusunun \%57'si yani 4 milyar 388 milyon kiși internet kullanmaktadır. ${ }^{3}$ Kullanım nedenlerinden bağımsız olarak ele alındığında bu rakam, internet ve yeni medya mefhumunun görmezden gelinemeyeceğinin bir göstergesidir. Yeni medya teknolojilerinin hızla gelişim göstermesi ve toplumsal yaşamdaki mevcut durumuna bakıldığında, geleneksel medyanın da yeni medya teknolojilerine eklemlendiği görülmektedir. Geleneksel formatta yayıncılık yapan kurum ve kuruluşlar, yeni medya teknolojilerini aktif olarak kullanmakta ve faaliyetlerini çift başlı bir şekilde yürütmektedirler. Bu bağlamda yeni medya teknolojilerinin belirli ölçüde bir toplumsal kabulunun olduğunu belirtmek gerekmektedir. Yeni medya ve sosyal medya üzerine yapmıș olduğu çalışmalarda sıklıkla yeni medya teknolojilerini Marksist bir perspektiften eleștiren Christian Fuchs, Arap Baharı ve 2011 yllında Birleşik Krallık'taki eylemlerde yeni medyanın sanıldığı kadar güçlü olmadığının altını çizerek, sorunun daha temelde olduğu vurgulamıştır (Fuchs, 2012). Fuchs'un yeni medyaya yönelik getirmiş olduğu eleştiri kısmen doğru olmakla beraber, tümüyle kabul edilebilir değildir. Yeni medya teknolojileri belirli toplumsal olayların direkt olarak kaynağı ve katalizörü olmasa da, toplumsal yönelimler ve katılım noktasında tümüyle işlevsiz değildir. Bu çerçevede internet ortamında toplanan ve birtakım mücadeleler yürüten oluşumlara ve bu oluşumların icraatlarına bakmak gerekmektedir.

Yeni medya ve internet teknolojilerinin gelișim göstermesiyle birlikte geleneksel olarak yürütülen örgütlenme ve bir araya gelme halinin internet ortamına kaydığı görülmektedir. Yeni medya teknolojileri sayesinde bireyler, benzer sorunlar etrafında bir araya gelebilmekte ve "kamuoyu" oluşturmaya çalışmaktadırlar. Bu noktada yeni medyanın işlevselliğinin tartışıldığını belirtmek gerekmektedir. Geleneksel medyadan yapısal olarak farklılıklar gösteren yeni medyaya yönelik bu bağlamda "distopik" ve "ütopik" yaklaşımların olduğunun da belirtilmesi gerekmektedir (Papacharissi, 2002, s. 10-12).

Zizi Papacharissi'nin sosyal medyayı kamusal alan üzerinden tartıştığı çalışmada belirtmiş olduğu distopik ve ütopik yaklaşımlar ekseninde yeni medyayı ele almak yerine, yeni medyanın toplumsal çıktıları ekseninde değerlendirilmesi önem arz etmektedir. Bu bağlamda yeni medya araçlarının muhtevasının bir kenara bırakılarak, kullanım amaçlarının ve sonuçlarının tartışılması gerekmektedir. Dolayısıyla biyolojik yurttaşlık olgusunu yeni medya kavramı üzerinden tartışma bu çerçevede önemli görülmektedir. Yeni medya teknolojilerinin gelişim göstermesiyle beraber, biyolojik yurttaşlığın da dijitalleşmeye başladığı ileri sürülebilir. Belirli biyolojik ve bedensel hastalıklar etrafında örgütlenen yurttaşlar olarak tanımlanan biyolojik yurttaşlar, internet ve yeni medya teknolojileri aracıllğıyla dijital ortamlarda örgütlenip, seslerini duyurabilmektedirler (Greenhough, 2014, s. 2; Rabinow, 2005, s. 49).

Biyolojik yurttaşlığın dijitalleşmesi bağlamında, bireylerin internet ortamında küresel düzlemde bir araya gelerek, ortak çlkarlar doğrultusunda hareket edebildiklerini belirtmek gerekmektedir. Özellikle küresel ölçekte önemli görülen salgınlar, AIDS vb. hastalıklara karşın yurttaşlar, benzer platformlarda buluşarak, biyolojik yurttaşlık vazifelerini yerlerine getirmektedirler. Bu bağlamda yeni medya teknolojilerinin sağlamış olduğu avantajlardan birisinin biyolojik yurttaşlık olgusunun dijitalleşmesi olduğu ileri sürülebilir. Bu bağlamda biyolojik olarak benzer koşullara sahip olan bireylerin e-mail listeleri ya da internet siteleri aracılığıyla bir araya gelmeleri sonucunda oluşturmuş

${ }^{3}$ https://wearesocial.com/global-digital-report-2019, e.t: 12.03.2019 
oldukları yapı "dijital biyolojik yurttaşlık" olarak tanımlanmaktadır (Johnson vd, 2018, s. 6). Dolayısıyla yeni medya ve internet teknolojilerinin, biyolojik yurttaşlık olgusunda da değişimler ve dönüşümler yarattığını belirtmek gerekmektedir. İnternet teknolojileri sayesinde zaman ve uzamdan bağımsız olarak hareket edebilen benzer sağlık sorunlarına sahip olan katılımclar, belirli online platformlarda bir araya gelerek, hak taleplerini iktidarlara iletmektedirler. Bu bağlamda yeni medya ve internet teknolojilerinin toplumsal çıtısı olarak biyolojik yurttaşlık olgusunun dijitalleşmesi, bu bağlamda önem arz etmektedir. Türkiye özelinde dijitalleşen biyolojik yurttaşlık olgusuna bakıldığında ise change.org platformu üzerinden yürütülen kampanyaları, bu bağlamda dikkat çekmektedir. Change.org platformunun yayımlamış olduğu 2018 yılı faaliyet raporuna göre, biyolojik yurttaşlık kapsamında değerlendirilecek birçok kampanya başlatılmış ve başarılı/başarısız sonuçlar elde edilmiştir. Dolayısıyla dijitalleşme ve biyolojik yurttaşlık kapsamında change.org platformunun incelenmesi bu bağlamda önem arz etmektedir.

\section{Tartışılması}

Change.Org Verilerine Göre Türkiye'de Biyolojik Yurttaşlık Olgusunun

Change.org'un 2018 yılı faaliyet raporuna ilişkin verilerin analizi yapılmadan önce Change.org platformuna dair birtakım bilgiler vermek, olayın mahiyetini kavrayabilmek noktasında önem arz etmektedir. Change.org, 2007 yılında Ben Rattray tarafından Amerika Birleşik Devletlerin'de kurulmuş özel bir şirkettir. Kendisini sosyal, gönüllü ve kâr amacı gütmeyen bir platform olarak tanımlayan change.org, uluslararası arenada kampanyaların yürütüldügü bir sitedir. Güncel verilere göre, 279 milyon 861 bin $656^{4}$ kişinin harekete geçtiği bir platform olarak change.org, 196 ülkede faaliyet göstermektedir. Kendisini açık bir platform olarak tanımlayan Change.org'da tüm kampanyalar kullanıcılar tarafından başlatılmaktadır. Bu çerçevede change.org sadece bir platform olarak faaliyet göstermektedir. Ayrıca change.org yönetimi, herhangi bir hakemlik görevi üstlenmemekte, isteyen her kullanıcl, her konuda kampanya başlatabilmektedir. Ayrıca change.org platformu, başlatılan kampanyalara ilişkin taraf değildir ve kampanyaların başarı ya da başarısızlıklarının sorumluluğunu üstlenmemektedir. Bu bağlamda bir internet sitesi olarak change.org, toplumsal ya da özel sorunlardan hareketle imza kampanyalarının başlatıldığı bir platform olarak kabul edilmektedir. Change.org'a ilişkin bir diğer önemli husus ise, change.org'un bir sivil toplum kuruluşu değil, teknolojik bir şirket olduğudur. Change.org platformunda sağlıktan, ekonomik adalete; insan haklarından, çevre hakkına kadar birçok alanda kampanyalar başlatılmaktadır. Bu çerçevede yapılmış olan bu çalışmada change.org'un yayımlamış olduğu 2015, 2016, 2017 ve 2018 yılı faaliyet raporları baz alınarak, sağlık alanında başlatılan kampanyalar, biyolojik yurttaşlık ekseninde tartışılmıştır.

\begin{tabular}{|c|c|c|c|c|c|}
\hline Yıllar & $\begin{array}{c}\text { Toplam } \\
\text { Kampanya } \\
\text { Sayısı }\end{array}$ & $\begin{array}{c}\text { Toplam } \\
\text { İmza } \\
\text { Sayısı }\end{array}$ & $\begin{array}{c}\text { Sağlık } \\
\text { Alanında } \\
\text { Başlatılan } \\
\text { Kampanya } \\
\text { Sayısı }\end{array}$ & $\begin{array}{c}\text { Sağlık } \\
\text { Alanında } \\
\text { Başlatılan } \\
\text { Kampanyaların } \\
\text { İmza Sayısı }\end{array}$ & $\begin{array}{c}\text { Sağlık Alanında } \\
\text { Başlatılan } \\
\text { Kampanyalardan } \\
\text { Başarıya Ulaşların Sayısı }\end{array}$ \\
\hline 2018 & 44.372 & 27.052 .322 & 10.205 & 6.244 .713 & 9 \\
\hline 2017 & 44.430 & 14.795 .295 & 4.443 & 1.479 .529 & 6 \\
\hline 2016 & 34.805 & 16.157 .892 & 3828 & 1.615 .789 & 11 \\
\hline 2015 & 23.263 & 15.811 .872 & 1628 & 1.871 .483 & 15 \\
\hline
\end{tabular}

Tablo 1: Change.org 2018 raporuna göre Türkiye'de sağlık alanındaki kampanyalar5

\footnotetext{
${ }^{4}$ https://www.change.org/tr, e.t: 20.03.2019

5 https://www.change-destek.org/2018/, e.t: 20.03.2019
} 
Tablo 1'de görüldüğü üzere 2018 yılında Türkiye'de change.org platformu üzerinden toplam 44 bin 372 adet kampanya başlatılmış ve bu kampanyalara toplam 27 milyon 52 bin 322 adet imza atılmıştır. Çalıșma sınırlılığında yer almasında ötürü, bu çalıșmada sadece sağlık alanında başlatılan kampanyalara yer verilmiștir. 2018 yılında change.org platformu üzerinden sağlık alanında 10 bin 205 adet kampanya başlatılmıș ve bu kampanyalara toplam 6 milyon 244 bin 713 adet imza atışmıştır. Başlatılan kampanyalardan 9 tanesi ise başarılı bir şekilde sonuçlanmıştır. Bu çerçevede sayısal verilerden hareket edilecek olursa, başarıya ulaşan 9 kampanya, biyolojik yurttaşlık çerçevesinde değerlendirilebilir. Change.org platformunun 2017 raporunda da benzer bir sonuç gözlemlenmektedir. 2017 yılında toplamda 44 bin 430 kampanya başlatılmış olup, sağlık alanında yürütülen 4 bin 443 adet kampanyaya atılan imza sayısı 14 milyon 795 bin 295'tir. 2017 yılında sağlık alanında başarıya ulaşan kampanya sayısı ise 6'dır. Bir önceki yıla göre niceliksel bir artışın olması, dijital aktivizmin gün geçtikçe yaygınlaştığının bir göstergesi olarak değerlendirilebilir. Change.org platformunun yayımlamış olduğu 2016 yılı raporunda ${ }^{6}$ ise sağlık alanında başlatılan 3828 kampanyadan on bir tanesi başarıya ulaşırken; 2015 yılında başarıya ulaşan kampanya sayısı ise on beștir.7 $^{7}$

Başarıya ulaşan kampanyalara bakıldığında down sendromlulara ilişkin Türkiye Büyük Millet Meclisi'nde komisyon kurulması, 2018 yılında başarıya ulaşan change.org kampanyaları arasında yer almaktadır. 93 bin 426 imzacının destek verdiği kampanya sonucunda Türkiye'deki 70 bin down sendromlu birey için, "Down Sendromu Araștırma Komisyonu" kurulmuştur (change.org, 2018). Bu bağlamda biyolojik yurttaşlık ekseninde harekete geçen bireyler, yeni medya ve internet teknolojilerinin bir ürünü olan change.org üzerinden taleplerini ileterek, biyolojik yurttaşlığın dijital alandaki ișlevselliğini göstermişlerdir.

Sağlık alanında başlatılan ve başarıyla sonuçlanan bir diğer kampanya ise biyonik kulaklarla ilgilidir. Sosyal Güvenlik Kurumu tarafından bir süre önce alımları durdurulan biyonik kulakların ișitme engelli bireyler için tekrardan tedarik edilmesine ilișkin başlatılan "Fatoşeylülüduysun" isimli kampanya, 102 bin 192 adet imza sonucunda başarıya ulaşmıștır. Ani İşitme Kaybı'na yakalanan ve işitme duygusuna kaybeden Fatoş isimli vatandaşın eşi, change.org üzerinden biyonik kulakların tekrar SGK tarafından karşılanmasına ilişkin başlattığı kampanya başarılı ile sonuçlanmıştır. Kampanyanın muhatabı olan Sağlık Bakanlığı, ilgili kurumla ihale sürecini tamamlayarak, biyonik kulakların alımına tekrar başlamıştır. Neticesinde ise hem kamu hem de özel hastanelerde biyonik kulak bekleyen diğer hastalara da beklemiş oldukları biyonik kulaklar ulaştırılmaya başlanılmıștır. Bu bağlamda biyolojik yurttaşlığın bir tezahürü olarak işitme engelli vatandaşların ve yakınlarının katılım sağladığı bu kampanya, biyolojik yurttaşlığın dijitalleşmesine ilişkin örnek olarak gösterilebilir.

Change.org platformu üzerinden sağlık alanında başlatılan ve başarıya ulaşan bir diğer kampanya ise Hazal Semiz isimli bebek üzerinden başlatılan Sipinal Müsküler Atrofi (SMA) hastalığı bir diğer tabirle "Gevşek Bebek Sendromu" tedavisinde kullanılan ilaçların SGK tarafından karşılanmasına ilişsin başlatılan kampanya, 2018 yılında 337 bin 88 adet imza toplayarak başarıya ulaşmıștır. Bir dozu yaklașık olarak 175 Bin Dolar olan ilacın SGK tarafından karşılanmasına ilişki harekete geçen bireyler, 1 milyon 300 bin SMA

\footnotetext{
${ }^{6}$ https://s3.amazonaws.com/change-production/cms uploads/Change org 2016 Raporu.pdf, e.t: 05.04 .2020

${ }^{7}$ https://s3.amazonaws.com/change-production/cms uploads/Change org 2015 raporu.pdf, e.t.: 05.04.2020
} 
hastası çocuk için başlatmış oldukları kampanyadan olumlu sonuç almışlardır. ${ }^{8}$ Biyolojik yurttaşlığın diğer örneğini teşkil eden bu kampanya, biyolojik yurttaşlık faaliyetlerinin dijitalleşmesinin bir başka örneği olarak kabul edilmektedir.

Change.org platformunda yürütülen ve bașarıya ulaşan bir diğer kampanya ise "MS hastalarının ilaçları (Gilenya, Tysabri, Fampyra) SGK kapsamına alınsın" kampanyasıdır. Multipl Skleroz (MS) hastalığına sahip olan bireyler, tedavileri için gerekli olan ilaçlarının Sosyal Güvenlik Kurumu (SGK) tarafından karşılanmamasına tepki göstermek amacıyla başlattıkları kampanya, 1399 imzacının desteğiyle (change.org, 2015) başarıya ulaşmıştır. Kampanya sonrasında Gilenya isimli ilaç, SGK tarafından karşılanmaya başlamıştır. Biyolojik yurttaşlar olarak nitelendirilebilecek olan MS hastaları, benzer bir amaç doğrultusunda dijital teknikleri kullanarak bir araya gelmişler ve seslerini duyurmuşlardır. Kampanya sonrasında alınan sonuç, dijital aktivist hareketlerin bir başarısı olarak değerlendirilebilir. Bu duruma benzer bir sonuç yine 2015 yılında "Devlet ilacımızı versin" isimli kampanya sonucunda ortaya çıkmıştır. Vücuttaki enzimlerin üretilememesi sonucunda ortaya çlkan Mukopolisakkaridoz (MPS) hastalarının tedavisinde kullanılan Vimizim isimli ilaç da SGK tarafından karşılanmaya başlamıştır.

$\mathrm{Bu}$ çerçevede çalışma sınırlılığında yer alan ve sağlık alanında başarıya ulaşan farklı kampanyaların ortak noktasının biyolojik yurttaşlık olduğunu belirtmek gerekmektedir. Benzer hastalıklara sahip bireyler ve yakınlarının bir araya gelerek oluşturmuş olduğu biyolojik yurttaşlık olgusu, yeni medya teknolojilerinin gelişim göstermesiyle beraber dijitalleşmeye bașlamıștır. Bu bağlamda change.org platformu, biyolojik yurttaşlık faaliyetlerinin yürütüldügü bir platform olarak değerlendirilebilir.

\section{Sonuç}

Biyolojik yurttaşlık olgusu, yurttaşlık ve sosyal adalet ekseninde önemli bir tartışma konusudur. Biyolojik olarak benzer hastalıklara ve kusurlara sahip bireyler ve yakınlarının bir araya gelerek olușturmuș oldukları biyolojik yurttaşlık tipinin ayırt edici özelliği, biyolojik sorunlar üzerinden temelleniyor olmasıdır. $\mathrm{Bu}$ bağlamda biyolojik yurttaşlık ekseninde bir araya gelen bireyler, iktidarlardan birtakım taleplerde bulunmaktadırlar. Biyolojik sorunlar ekseninde meydana gelen biyolojik yurttaşlık faaliyetinin kavramsallaştırıldığı ilk olay, Ukrayna'da meydana gelen Çernobil Nükleer santralinde yaşanan faciadır. Genel olarak bakıldığında ise biyolojik yurttaşlık olgusunun, farklı türden hastalıklar etrafında bir araya gelen bireyler tarafından oluşturulduğu ileri sürülebilir. Özellikle kanser hastaları, AIDS hastaları, Down sendromlu bireyler gibi biyolojik hastalıklar ekseninde bir araya gelen bireyler, çeşitli platformlarda seslerini duyurmaya çalıșmakta ve birtakım taleplerde bulunmaktadırlar. Bu bağlamda biyolojik yurttaşların bir araya gelmesinde ve eyleme yönelik bir katılım gerçekleştirilmesinde yeni medya ve internet teknolojilerinin de işlevsel olduğunun belirtilmesi gerekmektedir. İnternet üzerinden birbirleriyle iletişime geçen ve örgütlenen bireyler bu çerçevede dijital biyolojik vatandaşlar olarak tanımlanabilmektedir. Yapılmış olan bu çalışmada da yeni medya ve internet teknolojileri ekseninde biyolojik yurttaşlık olgusu tartışılmıştır. Change.org özelinde yapılan çalışmada, belirli hastalıklara sahip bireyler, bu bireylerin yakınları ve diğer katılımcılar tarafından desteklenen kampanyaların, bir biyolojik yurttaşlık eylemi olduğunu belirtmek gerekmektedir. Çalışma sınırlılığında incelenen biyokulak talepleri, ya da SMA hastalarının kullanmış olduğu ilaçları SGK kapsamına

\footnotetext{
${ }^{8}$ https://www.change.org/p/sma-hastas\%C4\%B1-hazal-bebe\%C4\%9Fin-1-dozu-175-bin-dolarolan-ila \%C3\%A7lar\%C4\%B1n\%C4\%B1-sgk-\%C3\%BCstlensin/u/24231285, e.t: 20.03.2019
} 
alınmasına ilişkin başlatılan kampanyalar, biyolojik yurttaşlık eylemlerinin bir tezahürü niteliği taşımaktadır. Ayrıca MS ve MPS hastalarının kullandığı ilaçların da SGK kapsamına alınması da biyolojik yurttaşlık ve dijital aktivizmin kesiştiğinin bir göstergesidir.

Change.org, tarafsız ve kâr amacı gütmeyen bir platform olarak, bireylere birçok alanda kampanya başlatabilme olanağı sunmaktadır. Bu çalışmada, Change.org platformunun 2015, 2016, 2017 ve 2018 yıllarına özel yayımlamış olduğu raporlar temel alınarak, sağlık alanında başlatılan ve başarıya ulaşan beş farklı kampanya incelenmiştir. Kampanyaların ortak noktasının biyolojik kökenli olması ve benzer hastalar tarafından desteklenmesi, bu kampanyaları direkt olarak biyolojik yurttaşlık faaliyeti kılmaktadır. Dolayısıyla yeni medya ve internet teknolojilerinin bir artısı olarak değerlendirilebilecek olan change.org tarzı platformlar, biyolojik yurttaşlar için hareket sahası yaratmakta ve seslerini duyurabilmelerine imkân sağlamaktadır. Yeni medya teknolojilerini tümüyle olumlamak ya da yansımak mümkün değildir. Toplumsal ișleve sahip her șeyin artıları ve eksileri olabileceği gibi, yeni medya ve internet teknolojilerinin de artıları ve eksileri bulunmaktadır. Bu noktada olaylara ve olgulara nereden bakıldığı önem arz etmektedir. Change.org platformuna, biyolojik yurttaşlık ekseninde bakıldığında, her ne kadar 2018 yılında sağlık alanında başlatılan kampanyalardan 9'u, 2017 yılındaki kampanyalardan ise 6'sı 2016 yılındaki kampanyaların on bir tanesi ve 2015 yılındaki kampanyaların ise on beşi başarıya ulaşmıştır. Bu veriler, yeni medya teknolojilerinin tümüyle işlevsiz olmadığının bir göstergesidir. Biyolojik yurttaşlık ekseninde değerlendirildiğinde change.org, dijital aktivizmin gerçekleștiği bir platform olarak değerlendirilebilir.

Biyolojik yurttaşlık ve dijitalleșen biyolojik yurttaşlık ekseninde Change.org'da başlatılan sağlık alanındaki kampanyalar, biyolojik yurttaşlık olgusunun modern toplumlardaki bir yansıması niteliğini taşımaktadır. Dolayısıyla sonuçlarından bağımsız bir şekilde başarıya ulaşsın ya da ulaşmasın sağlığa yönelik her biyolojik yurttaşlık eylemi, yeni medya ve internet teknolojilerinin avantajları kapsamında değerlendirilmelidir.

\section{KAYNAKÇA}

BİNARK, M. (2007). Yeni medya çalışmalarında yeni sorular ve yöntem sorunu, (Editör) Mutlu Binark. Yeni medya çalışmaları. Ankara: Dipnot Yayınları, s. 21-45. CASTELLS, M. (2008). Enformasyon çağı: ekonomi, toplum ve kültür: ağ

toplumunun yükselişi. (Çev: Ebru Kılıç), İstanbul: Bilgi Üniversitesi Yayınları.

CHIBATA, M. B. (2016). Digital activism in Uganda, (Ed), Bruce Mutsvairo. Digital Activism in the Social Media Era. London: Palgrave Macmillan. s. 69-95.

COOTER, R. (2008). Historical keyword: biocitizenship. The Lancet. Vol: 372, s.1725.

DENNIS, J. (2019). Beyond slacktivism: political participation on social media. Canberra: Palgrave Macmillan.

FUCHS, C. (2012). Behind the news social media, riots and revolutions. Capital \& Class, 36(3), s. 383-391.

GREENHOUGH, B. (2014). Biopolitics and biological citizenship, (Eds), William Cockerham, Robert Dingwall ve Stella Quah. Wiley Blackwell Encyclopedia of Health, Illness, Behavior, and Society. New Jersey: Wiley Publishing, s. 1-3.

HALSE, C. (2009). Bio-citizenship: virtue discourses and the birth of the bio-citizen. (Editörler), Jan Wright ve Valerie Harwood. Biopolitics and the obesity epidemic: governing bodies, London: Routledge Press. s. 45-59. 
JOHSON, J. HAPPE, K. ve LEVINA, M. (2018). Introduction. (Eds), Kelly Happe, Jenell Johnson ve Marina Levina. Biocitizenship: the politics of bodies, governance, and power. New York: New York University Press, s. 1-21.

PAPACHARISSI, Z. (2002). The virtual sphere: the internet as a public sphere. New Media \& Society, 4(9), s. 9-27.

PETRYNA, A. (2002). Life exposed: biological citizens after chernobyl. New Jersey: Princeton University Press.

PLOWS, A. \& BODDINGTON, P. (2006). Troubles with biocitizenship?. Genomics, Society and Policy, 2(3), s. 115-135.

RABINOW, P. (2005). Midst anthropological problems. (Eds), Aihwa Ong ve Stephen Collier. Global Assemblages: Technology, politics and ethics as antropological problems, Victoria: Blackwell Publishing, s. 40-55.

RADSCH, C. C. (2016). Cyberactivism and citizen journalism in egypt. Maryland: Palgrave Macmillan.

ROSE, N. (2008). The value of life: somatic ethics \& the spirit of biocapital. Daedalus, 137(1), s. 36-48.

ROSE, N. ve NOVAS, C. (2005). Biological citizenship. (Eds), Aihwa Ong ve Stephen Collier. Global assemblages: technology, politics and ethics as antropological problems. Victoria: Blackwell Publishing, s. 439-464.

TERZIOĞLU, A. (2011). Küreselleșme, kanser ve hastalık anlatıları: bilinçli/bilinçsiz hastadan biyolojik vatandaşlığa geçiş, (Eds), Cenk Özbay, Ayșecan Terzioğlu ve Yeşim Yasin. Neoliberalizm ve mahremiyet. İstanbul: Metis Yayınları, s. 111133.

\section{İnternet Kaynakları}

https://www.change.org/p/sma-hastas\%C4\%B1-hazal-bebe\%C4\%9Fin-1-dozu175-bin-dolar-olan-ila\%C3\%A7lar\%C4\%B1n\%C4\%B1-sgk-

\%C3\%BCstlensin/u/24231285, e.t: 20.03.2019

https://www.change-destek.org/2018/, e.t: 20.03.2019

https://www.change.org/tr, e.t: 20.03.2019

https://wearesocial.com/global-digital-report-2019, e.t: 12.03 .2019

https://s3.amazonaws.com/change-

production/cms uploads/Change org 2015 raporu.pdf, e.t: 05.04.2020

https://s3.amazonaws.com/change-

production/cms_uploads/Change_org_2016_Raporu.pdf, e.t: 05.04.2020

\section{Summary}

Nowadays, biological citizenship is a term frequently mentioned in health and body politics. The concept of biological citizenship first coined by Adriana Petryna is primarily used to characterize the community of individuals with similar biological disorders. The concept of biological citizenship used by Petryna in his study on the Chernobyl Nuclear Power Plant Disaster underlines that a different definition of citizenship can be made. When the development of new media and internet technologies and the fact that the collective structures organized on the internet become visible on the social strata, it can be observed that the biological citizenship in a digital media. In this study, the relationship between the phenomenon of biological citizenship and the new media was examined and inferences were made for the digitalization of the phenomenon of biological citizenship. In the context of the advantages offered by new media and internet technologies to its users, biological citizens 
can organize on the internet and convey their demands to the relevant institutions. In this context, it is observed that biological citizens can create public opinion through new media and internet technologies. The aim of this study is to emphasize that in the context of new media and internet technologies, the phenomenon of biological citizenship has begun to digitalize. In this context, the study was carried out on the Change.org platform as a product of new media and internet technologies. This study is limited to the field of health campaigns launched in Turkey in 2018. According to the Change.org platform's, in 2018 a total of 273 campaign started in Turkey in the health field and 9 of them have resulted in the success of these campaigns. In this study, 3 of the 9 campaigns that have been successful with judicial sampling technique were examined in the study limitation and biological citizenship and internet relationship were examined. The method of literature review was used as a method in this study and the relationship between the phenomenon of biological citizenship and internet technologies is discussed in terms of campaigns launched at the change.org platform. 